\title{
NEW LOCALITIES OF CEPAEA VINDOBONENSIS (FÉRUSSAC, 1821) (GASTROPODA: PULMONATA: HELICIDAE) IN WIELKOPOLSKA (W POLAND)
}

\author{
ELŻBIETA KORALEWSKA-BATURA ${ }^{1}$, ANDRZEJ DZIABASZEWSKI ${ }^{2}$ \\ ${ }^{1}$ Deparment of General Zoology, ${ }^{2}$ Department of Animal Morphology, Institute of Environmental \\ Sciences, Adam Mickiewicz University, Fredry 10, 61-701 Poznań, Poland
}

ABSTRACT: Cepaea vindobonensis (Férussac, 1821) is recorded from two new localities in the Wielkopolska region, W Poland. The sites are located outside the continuous distribution range of the species, probably as remains of its more numerous insular localities in the Warta river valley.

KEY WORDS: Cepaea vindobonensis, Helicidae, geographic distribution, range, W Poland

Cepaea vindobonensis (Férussac, 1821) lives in habitats of steppe and forest-steppe characters, among dry shrubs, on sunny hills and river banks, and in xerothermic grasslands; it also occurs in gardens and cemeteries. It climbs tall herbs and shrubs.

C. vindobonensis is a south-eastern European species. The north-western part of its continuous distribution range covers the northern Caucasus, Crimea and the Balkan Penisula up to eastern Austria, the former Czechoslovakia and south-eastern Poland. The species does not occur in the Polish mountains Carpathians, Sudetes and Łysogóry (RIEDEL 1988). Its northern distribution border runs near Puławy in Poland. Farther to the north, there are only insular localities, e.g. along the lower Vistula river (POLIŃSKI 1924). Isolated locialities are known from Western Pomerania and the valley of upper Elbe (RIEDEL 1988).

According to URBAŃSKI (1935), the isolated populations of $C$. vindobonensis along the Vistula river, like those of other animal and plant species, may have been founded by individuals brought by the river current. The author listed two regions of its occurrence in Wielkopolska (W Poland): one, upon the Noteć river, connected with the isolated localities along the Vistula; another extending along the Warta river. $C$. vindobonensis lived in the Warta river valley in the vicinity of Poznań not long ago; URBAŃSKI (1938) suggested that it had become extinct in that valley rather recently and later (URBAŃSKI 1948) added that "it slowly becomes extinct in Wielkopolska and southern Polish lakelands (apart from the Vistula valley)". At present, the species occurs in the Wielkopolska region only at few localities isolated from the continuous distribution range (KORALEWSKA-BATURA 1992).

New localities in Wielkopolska, reported in this paper, are: XU07 - Radolinek between Czarnków and Trzcianka, xerothermic slope and XU31 - Poznań, grass on sandy ground.

The locality in Radolinek is situated within URBAŃSKI's (1935) upon-the-Noteć region of its occurrence in Wielkopolska. Only few specimens were collected at this locality.

The Poznan locality is situated in the Nowe Miasto district of the city, on the right bank of the Warta river (ca. $25 \mathrm{~m}$ from the river), near the busy Hetmańska street. C. vindobonensis occupies about $800 \mathrm{~m}^{2}$ of undulating area, covered mainly by a xerothermic grassland (Fig. 1). Based on the presence of the characteristic species Silene tatarica Pers., as well as other diagnostic species: Festuca pseudovina (Hackel ex Celak.) Fritsch, Festuca trachyphylla (Hackel) Krajina, Trifolium arvense L., Trifolium pratense Schreb. and Artemisia campestris L., the phytocoenosis was identified as Corynephoro-Silenetum tataricae Libb., 1931. A part of the locality is covered by the association identified as Calamagrostietum epigeios Juraszek, 1928 of grassy character, dominated by Calamagrostis epigeios (L.), with 


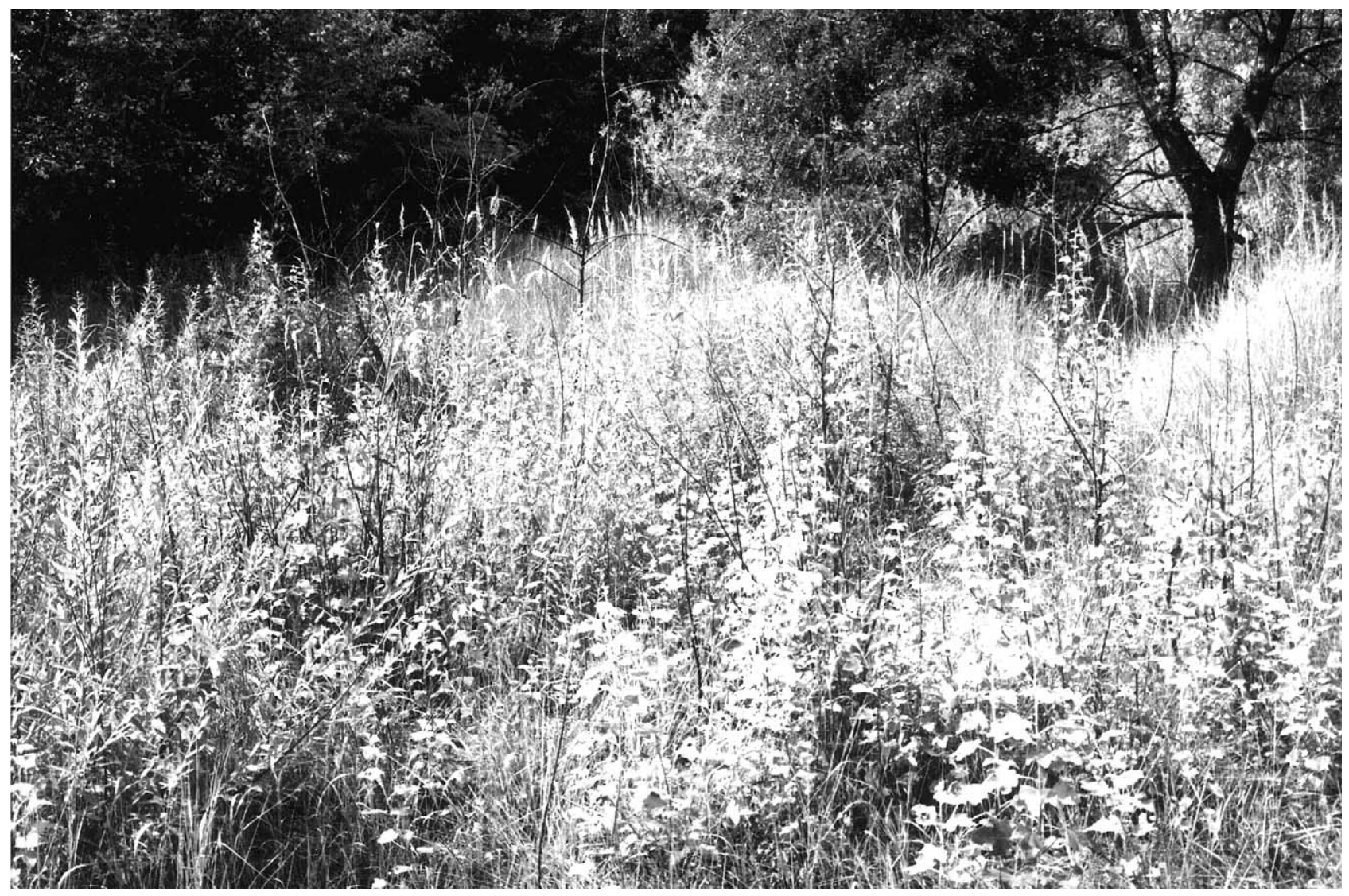

Fig. 1. A fragment of the study plot in the Warta river valley in Poznań

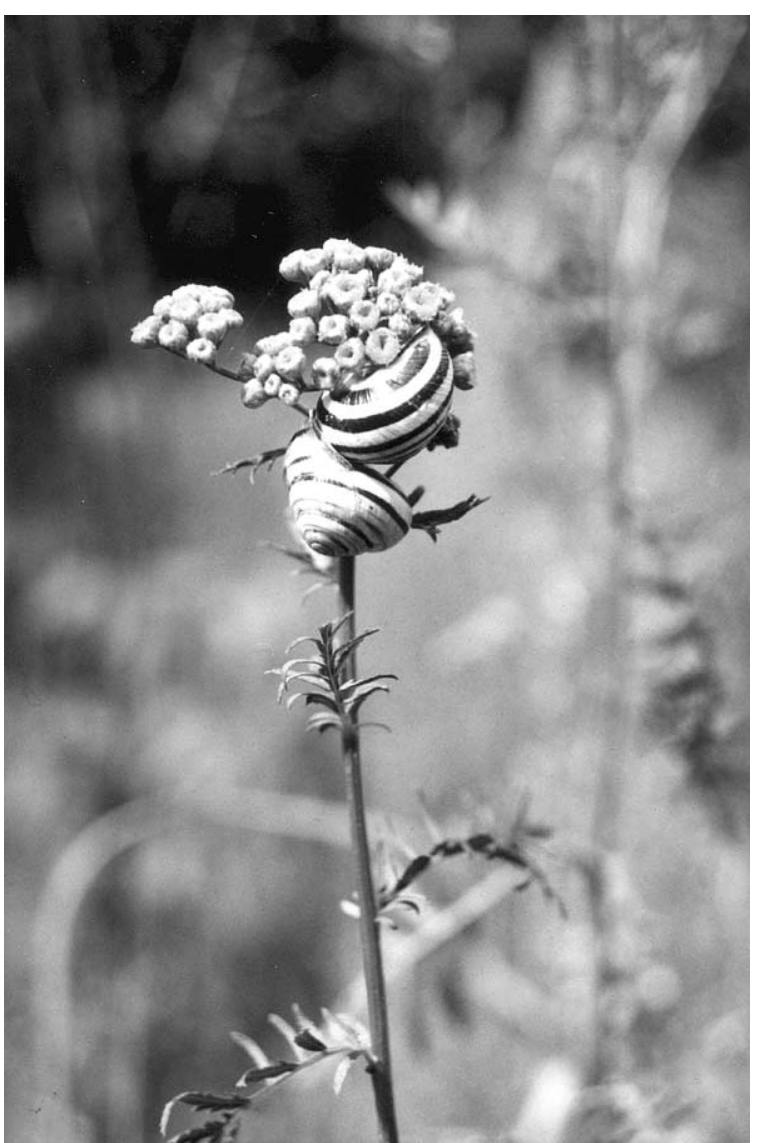

Poa angustifolia L. and Festuca rubra L. Besides, there are Tanacetum vulgare L., Oenothera biennis L., Melilotus officinalis (L.) and Artemisia vulgaris L. Within the area of both plant associations, there occur Salix purpurea L. and young specimens of Populus alba L., Salix fragilis L., Salix alba L. and Robinia pseudoacacia L.

C. vindobonensis occurs abundantly at this locality. On July 6th and 9th 1999, we collected 340 specimens, including 63 young, within three hours. All of them were sighted specimens, found sitting either high on plants and dry twigs or, rather rarely, in the undergrowth. Their apertures were covered with mucus membranes protecting the snails against drying in the hot conditions of the herb layer (Fig. 2). C. vindobonensis was accompanied by Helicella obvia (Menke), Cepaea nemoralis (L.) and Helix pomatia L.

Only 40 specimens out of 277 adults had their shells covered with a well preserved yellow periostracum. The remaining adults had their periostracum either damaged (151 specimens) or were devoid of it (86 specimens). The colour of these shells varied from yellow-whitish to whitish. The lips of all the specimens were beige, very characteristic for the species. Most specimens had five wide dark brown bands on the whole shell and two subtle beige bands

Fig. 2. C. vindobonensis (Fér.) on a herb in the study plot 


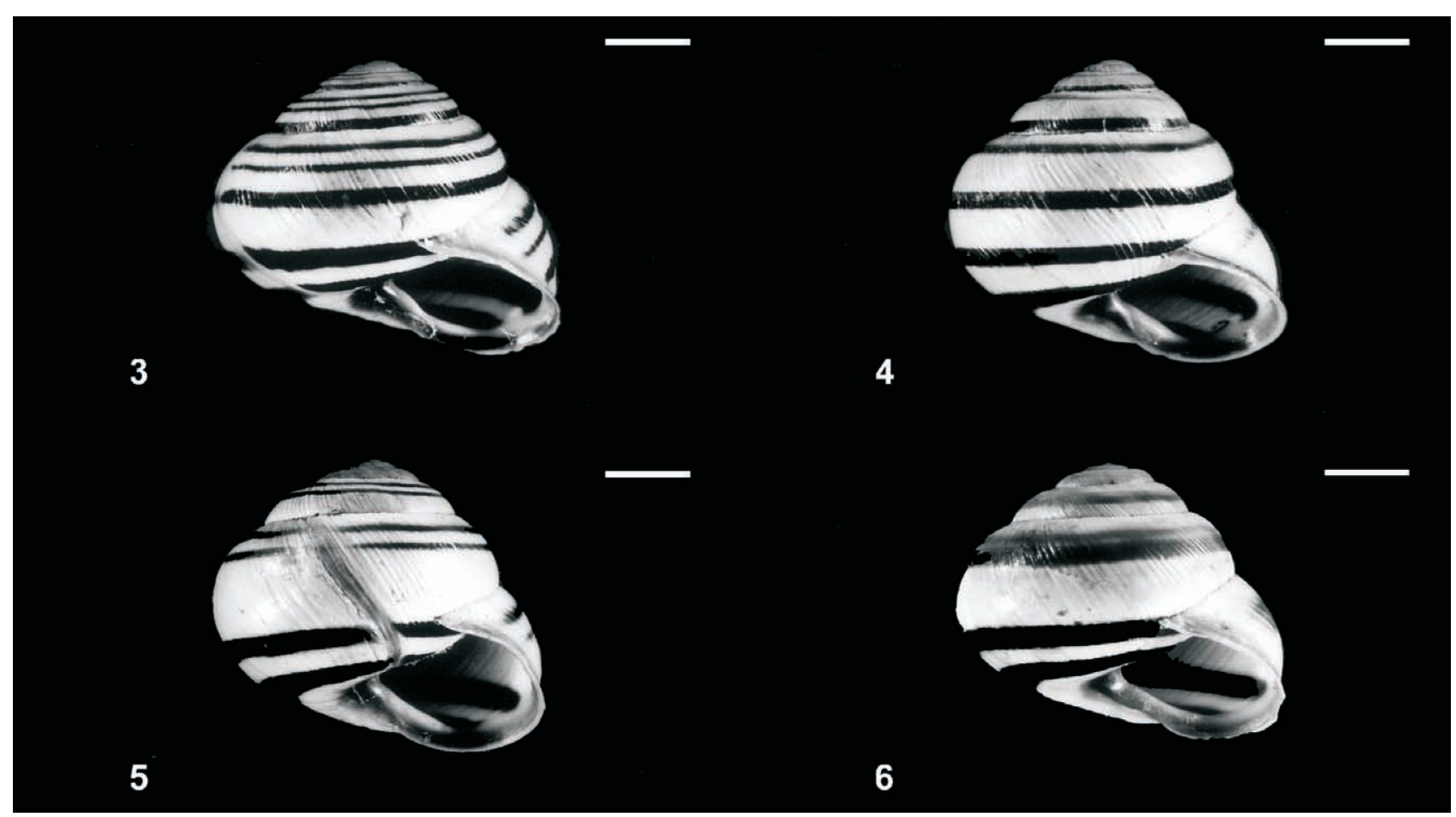

Figs 3-6. Shell banding of C. vindobonensis (Fér.): $3-5$ wide and 2 narrow bands; $4-5$ wide and 1 narrow band; 5 - 2 wide and 2 narrow bands; $6-2$ wide and 2 fused narrow bands; scale bars $-5 \mathrm{~mm}$

on each whorl (Fig. 3). Less often the whorls bore only one subtle beige band (Fig. 4). Only two specimens had shells with two dark brown bands. One of these shells had two usual beige bands, and the bands fused into one wider streak in the second specimen (Figs 5, 6). The shells ranged from 18.9 to 22.8 $\mathrm{mm}$ in width and from 16.4 to $20.8 \mathrm{~mm}$ in height.

The newly discovered localities of $C$. vindobonensis confirm URBAŃSKI's (1935) data on its occurrence in the Wielkopolska region. Hovewer, it appears that, contrary to his opinion, C. vindobonensis is not becoming extinct in the Warta river valley in the vicinity of Poznań. It has quite a large insular locality in the Warta river valley in Poznań. Moreover, the studied population consists of adult and young specimens; the condition of periostractum of adult shells indicates that it is probably an older population, living at the old locality, which may be treated as a remnant of more numerous sites in the Wielkopolska region.

\section{REFERENCES}

KoraleWSKA-BATURA E. 1992. Mięczaki (Mollusca) Wielkopolski. Wydawnictwo Naukowe Uniwersytetu im. A. Mickiewicza, Poznań, ser. zool. 18.

POLIŃSKI W. 1924. Anatomisch-systematische und zoogeographische Studien über die Heliciden Polens. Bull. Acad. Pol. Sci. Lett., Cl. Sci. Math. Nat., B, Cracovie, 1924: 131-279.

URBAŃSKI J. 1935. Dwa ciekawe gatunki ślimaków w Wielkopolsce. Wyd. Okr. Kom. Ochr. Przyr. Wlkp. Poznań 5: $108-114$

URBAŃSKI J. 1938. Beiträge zur Kenntnis der Molluskenfauna der Wojewodschaft Poznań. II. Fragm. Faun. 3: 439-467.

URBAŃSKI J. 1948. Reliktowe mięczaki ziem polskich i niektórych krajów przyległych. Ochr. Przyr. 18: 66-95.

received: August 1st, 2000

accepted: September 25th, 2000 